\title{
THE DEVELOPMENT OF EDUCATION IN BULGARIA
}

\author{
Venelin Terziev \\ Academician of the Russian Academy of Natural History, Moscow, Russia, \\ Prof. D.Sc. (Ec.), D.Sc. (National Security), D.Sc. (Social Activities), Ph.D., National Military \\ University, Veliko Tarnovo, Bulgaria; University of Rousse, Rousse, Bulgaria, terziev@skmat.com
}

\begin{abstract}
The aim of this study is to gather sufficient evidence and arguments in order to prove to society that during the process of change in thinking and especially of effective practical implementation of educational models such, high levels of efficiency can be achieved on all hierarchical levels in systems key for the society and the state.
\end{abstract}

Keywords: science, criterion, publications, impact factor, references.

\section{INTRODUCTION}

In the recent years, a lot is spoken about measuring science, about quality, about dimensioning in a way and finding an element for its valuating. Indisputably, this is connected with defining the remuneration of people, who have turned to such an activity. All, who are engaged with economy of labour and generally with human resources management, know how difficult and sometimes even impossible it is to give an adequate answer to such a question. The expertise of the one, who would evaluate, dimension and even give an account of this activity, should be high enough, and the evaluation - just and true enough in order to be accepted by the monitored and evaluated one. Applying and elaborating various models and technologies in this direction would always bring satisfied and unsatisfied. This shouldn't in any way frighten, insult or discourage either party. Achieving maximum justice is a strong enough motive for moving in this very direction of making objective the essential processes that are connected with scientific and researching activities. More, life proves the progress is connected with scientific findings.

\section{THE SCIENCE WE NEED IN ORDER TO PROGRESS}

We very often perceive the things rather pragmatically from our own point of view, being satisfied by the explanation they go well or in an acceptable way even at the moment. This acceptable way might be relatively good for a certain moment but by no means is acceptable and positive for the science process's progress. I repeatedly mention the word "process“, because I consider it is with long time duration and has its characteristic features, complexity and even contradiction. It should be reviewed, defined and even rationalized by all its participants but mainly by the users. The opposite would be an end in itself playing science and would bring satisfaction to the person for himself without being useful for the others around. You'd agree that the main benefit in this sense is the applicability of all that scientists and researchers do. In historical aspect, this has repeated long enough in the course of years, and in not so few cases, scientific 
findings have been accepted and evaluated in a much later period. The acceptance or denial of a certain scientific activity requires its understanding, perception or approval by the society. This is not always an easy and achievable task of one or a group of researchers. Usually, scientific findings, researches or works are published in specialized editions that are accessible for a limited circle of people or these editions are not public enough. This complicates the process of approving or perceiving the circumstances additionally. The established necessity the scientific works to be published in referred editions, i.e. ones that contain scientific information of high value, has turned them into editions of closed or limited nature of accessibility of the published information. This is also understandable, considering the efforts and work of the relevant teams or the certain researchers to get a feedback of their efforts and to be evaluated in a proper and acceptable way $(2019,2019 a)$.

On the other hand, scientists' work should reach wider community because practically it is the potential user of their work. This forces, or the right word is, perhaps, obliges scientists and researchers to present their thesis, works and findings at various forums in order to reach maximum fast along various information channels to the user. Explained this way, it sounds rather simplified but is relatively true. One research is sometimes presented, advertised and showed at tens of scientific conferences, round tables, symposia and fairs and turns into complicated, difficult and time consuming process of establishing. The resistance on the behalf of the scientific community in such cases is serious because the search for not traditional approaches in scientific researches' establishing breaks the standard frame of slowness. This "annoys" the scientific community, which is quite introvert and even ossified in its understanding for scientific works popularization.

My understanding is that almost all variations of presenting are acceptable if they give good result and ensure reliable and authentic feedback. The interrelation between authors and users should be more than warm and open in order gaps, negatives or imperfections to be defined in sufficiently exact and correct way.

The changes in the Academic Staff Development Act and in the Regulations for its application seek for answers to these questions as they try to establish a system of criteria, which to be measurable for the relevant field of higher education and professional direction. This system is serviced by the National Center for information and documents to the Ministry of Education and Science. It is hard to say whether the quantity measures set in this model, could ensure the necessary quality covering. Particularly if considering that various systems for evaluation and feasibility as well as different requirements were in operation during various periods. Covering certain criteria up to date, leads sometimes to impossibility for some scientists to present adequate information, and the older information on paper bearers from older periods appears to be an additional difficulty.

This does not underestimate the efforts that are made in this direction - unified requirements to be introduced and these to be considered at the procedures for habilitation for associate professor and professor as well as at the educational and scientific degree "doctor" and the scientific degree "doctor of science ".

Naturally, they are differentiated by certain criteria, where the relative weight is put in number of basic directions: articles and reports, published in scientific editions, referred and indexed in worldwide popular data bases with scientific information; articles and reports, published in non-referred magazines with scientific reviewing or published in edited collective volumes; quotations in monographs and collective volumes with scientific reviewing; quotations or reviewing in non-referred magazines with scientific review; guidance of a successfully graduated Ph.D. candidate; published university textbook or textbook that is used in the school network, etc. Here particular significance is set for publications that are in the referred systems of Web of Science $\boldsymbol{n}$ Scopus. It is considered that the requirements with such publications are high enough and the published works' mark is high. This, of course, is matter of perception of the relevant evaluating body and one of the main criteria at evaluating the quality of scientific work of the individual himself and of the institution as a whole.

All this is also directly corresponding to various rating systems that consider particular articles in particular editions and classify the institution after these indicators, including reviews of these scientific reports, articles or announcements. This seems quite acceptable and adequate as technology of evaluation but the result does not always corresponds to the reality. Such an evaluation is also made in Bulgaria and in the end of each year the results from the previous one are presented. The time for evaluation is not accidentally chosen. Indexing of the relevant publications in both major systems is a long lasting period, and in some cases it continues over a year. Sometimes in these cases, there is possibility for part of the publishing activity of the scientists to be reported incorrectly and not precisely reported. In some of the higher schools, progress is due to one or several scientists, who have formed a team and have established themselves in the community and are able to freely publish in such type of editions. This distorts in a way the presented information and leads to quantity accumulations that do not correspond to the institution's overall evaluation. 
In some of the cases, if we exclude these few scientists form the structure of the relevant higher schools, the resulting data would be insignificant.

Another evaluating indicator is the time of occupying the particular academic position - if it is acceptable for the people, who are engaged only with this, then it is unrealistic and even unachievable for the others. It could not be objective enough at least because of the fact that the particular skills, knowledge and competencies are not always function of the time and its duration as a period.

"Detaching" the scientific research works from the social development is also major problem and not insignificant in its essence. Here the questions what does this serve us for, when and how it would be useful or would it be useful at all. We have to exclude the completely theoretical works that have other meaning and necessity.

The opinion of Celia Luterbacher from Switzerland is very interesting, where she makes interesting interpretations in this direction. She shares that one ruthless principle is ruling within the scientific community „I publish, so I exist". In this direction are the thoughts that special meaning is given to the quantity measures, which consider the number of publications and the referrals to them. A reform is under preparation in Switzerland that is connected with change in this direction. „In the recent years quantity indicators more and more often are used for the sake of the quality ones and practically there is no way to motivate scientists, not to speak that this process could reduce the scientific researches' quality. All this would due be connected with change of the national strategy, which to consider the various disciplinary and institutional requirements, while applying differentiated evaluating practices".

Introducing such evaluating systems would also raise number of questions and critical notes. The first one among them is who and in what way would make this quality evaluation. Up to now, the adopted technology is the $\mathrm{h}$ index, which considers the relevant number referrals to a certain article and the other time indicator, which is used for the first one to be defined for the last 5 years. The various systems would show various figure evaluations because the information data bases are of different completeness and accessibility. Different ones could be used for the various fields of higher education, which again would give relatively true and exact information. Some would say that it is better there to be kind of system rather than there being no system and they would be absolutely right. The lack of system of measurable criteria led to a number of paradox differences in the levels of evaluation. I could not say whether this defines the quality of the candidate for a certain academic position, but it is a peculiar testimonial for the expertise of the corresponding commission. In this case this is a scientific jury, which to evaluate and rank the candidates. Usually, the competitions in our country are held with only one candidate. For some professional fields It is just the lack of other candidates, but sometimes it is also impossibility to occupy the relevant position because of number of objective circumstances. These circumstances are connected with difficulties in the development of academic structure in the recent decades, unattractiveness of the field or lack of financing for scientific researches. Sometimes the locality of the relevant higher school is unacceptable for the candidates, too. In other case only candidates from the interior environment are tolerated despite of the fact that the possible number from the exterior environment would be big enough. In this case the experts' work would be much more difficult and the competition - greater. The possible choice would fall on more than one candidate. Another issue of correctness is the following choice from the scientific and faculty council. In many cases, they are quite heterogeneous regarding fields and interests, convincing appear to be difficult and is not always connected with objective evaluation and in the long run - with correct choice. In this case, the question is whether these are competent enough to change the end result with their choice, despite the fact that this is integrated in their legal powers.

And if we leave this aside as a secondary problem, the searching and finding of appropriate candidates on this quite limited labour market of scientists and researchers leads to a closed cycle. It is not a secret that part of the universities is place of subsistence for whole families for years already. And there is nothing bad in it because a profession is handed down from one generation to another, but to what an extent the abilities of our children tally with our life ones and in particular, with our scientific interests. It is hardly this way, but it is an easy enough option, supported by the academic autonomy. Such a study would give frightening results of closeness and interrelations. Quite interesting developments are observed in the smaller communities, where the processes are self-regulated by this factor.

The change we have headed to looks for certain justice and accuracy, but would hardly achieve it only by these corrections in the legislation. It should rather be connected with such corrections in the management of the system. It is very often spoken about mandates, creativity, strategies and etc., in the most common case, connected with modeling the adjustments of the general assembly in a certain way, which sometimes is on the verge with the norms and the law. Despite that, the procedures are legal and not much moral. There are constantly many proofs in this direction. 
Not always the democratic rules choose the most skillful and the most competent, and sometimes they even don't give opportunity for contribution to part of the scientists because of a number of reasons.

This is a common problem, which is applicable with greater power for the academic community. Here individualities are many and in various directions. Sometimes the uniting is for the sake of a choice, which is rather connected with other circumstances, not with the individual's qualities. The change in this direction is possible if, at this choice, there is contest based on maximum objective criteria (Terziev, 2019b, Terziev, Stoyanov, Georgiev, 2017; Georgiev, 2019c).

\section{CONCLUSION}

My personal sense for satisfaction is rooted in the belief that the work of a scientist has certain extent of usefulness and significance and puts Bulgaria in standing out position in the scientific circles, in which we work. For me it is already clear that enmity, malice and even envy are characteristics that accompany the hard way. I put it on national peculiarities or on generation's changes. Anyway, we should not forget that efforts should be constant and progress in scientist's development should be looked for (Terziev, 2019d).

\section{REFERENCE LIST}

https://www.lex.bg/laws/ldoc/2135696665, (2019).

https://lex.bg/en/laws/ldoc/2135680028, (2019a).

Terziev, Venelin. (2019b). Naukata kato nauka, koyato ni tryabva da varvim napred. // Godishna mezhdunarodna nauchna konferentsiya na fakultet „Aviatsionen“ 2019, sbornik dokladi $11-12$ april 2019g., Natsionalen voenen universitet „Vasil Levski”, Fakultet „Aviatsionen”, Dolna Mitropoliya, str. 440-444, ISBN 978-954-713-123-1 (Терзиев, Венелин. Науката като наука, която ни трябва да вървим напред. // Годишна международна научна конфреренция на факултет „Авиационен“ 2019, сборник доклади 11 - 12 април 2019г., Национален военен университет „Васил Левски”, Факултет „Авиационен”, Долна Митрополия, стр. 440-444, ISBN 978-954-713-123-1).

Terziev, V., Stoyanov, E., Georgiev, M. (2017). Predpostavki za razrabotvane i vnedryavane na balansirana karta za otsenka vav voennoobrazovatelnata sistema. // Sbornik dokladi ot Godishna universitetska nauchna konferentsiya: 1-2 yuni 2017 g., Nauchno napravlenie „Sotsialni, stopanski i nauki”. Natsionalen voenen universitet "Vasil Levski", Veliko Tarnovo, 7, 2017, s.189-203, ISSN 1314-1937 (Терзиев, В., Стоянов, Е., Георгиев, М. Предпоставки за разработване и внедряване на балансирана карта за оценка във военнообразователната система. // Сборник доклади от Годишна университетска научна конференция: 1-2 юни 2017 г., Научно направление „Социални, стопански и науки". Национален военен университет "Васил Левски", Велико Търново, 7, 2017, c.189-203, ISSN 1314-1937).

Georgiev, Marin. (2019c). Modelat balansirana karta za otsenka kato instrument za usavarshenstvane na upravlenieto vav voennoobrazovatelnata sistema. // Godishna mezhdunarodna nauchna konferentsiya na fakultet „Aviatsionen“ 2019, sbornik dokladi 11 - 12 april 2019g., Natsionalen voenen universitet „Vasil Levski”, Fakultet „Aviatsionen”, Dolna Mitropoliya, str. 451-461, ISBN 978-954-713-123-1 (Георгиев, Марин. Моделът балансирана карта за оценка като инструмент за усъвършенстване на управлението във военнообразователната система. // Годишна международна научна конфреренция на фракултет „Авиационен“ 2019, сборник доклади 11 - 12 април 2019г., Национален военен университет „Васил Левски”, Факултет „Авиационен”, Долна Митрополия, стр. 451-461, ISBN 978-954-713-123-1).

Terziev, Venelin. (2019d). Science as science we need in order to progress in the social development. // The 25th International conference the Knowledge-based organization, Land Forces Academy „Nicolae Balcescu", Sibiu-Romania, Vol. XXV, 2019. 